\title{
Features of Information Coverage of Regional Environmental Policy on the Instance of the Republic of Tatarstan
}

\author{
Galina Viktorovna Morozova ${ }^{1} \&$ Irina Dmitrievna Porfireva $^{2}$ \\ ${ }^{1}$ Doctor of Economics, Professor of the Kazan Federal University, Institute of Social and Philosophical Sciences and \\ Mass Communications, Graduate School of Journalism and Media Communications, Head of the Department of \\ Public Relations and Applied Political Science, Kazan Federal University, Russia \\ ${ }^{2}$ Assistant at the Kazan Federal University, Institute of Social and Philosophical Sciences and Mass Communications, \\ Graduate School of Journalism and Media Communications, Department of Public Relations and Applied Political \\ Science, Kazan Federal University, Russia \\ Correspondence: Galina Viktorovna Morozova, Kazan Federal University, Russia. E-mail: galina.morozova@kpfu.ru \\ Received: October 9, 2020 \\ Accepted: December 2, 2020 \\ Online Published: January 14, 2021 \\ doi:10.5430/ijfr.v12n2p210 \\ URL: https://doi.org/10.5430/ijfr.v12n2p210
}

\begin{abstract}
The process of economic development of countries and the set of economic policies in recent decades has been such that environmental challenges have become one of the most important concerns of policymakers. Therefore, it can be important to study the role and impact of government economic policies on environmental quality. The pervasiveness of environmental consequences is one of the factors that make it necessary to examine its various dimensions in a wide range of political actions of governments. Therefore, many country leaders and environmental activists are trying to make policies to improve the environmental situation of their country. Environmental policy refers to commitments on environmental issues by organizing laws, regulations, policies and other political mechanisms. These issues generally include air, water, waste management, ecosystem management, biodiversity conservation, natural resource conservation, wildlife and endangered species. By monitoring human activities, these policies can prevent harmful effects on the biophysical environment and natural resources, as well as environmental changes and their harmful effects on human life. This study examines the environmental policies of the Republic of Tatarstan and the Ministry of Natural Resources and Ecology of the Russian Federation.
\end{abstract}

Keywords: environmental policy, Ministry of Ecology and Natural Resources (MENR) of the Republic of Tatarstan, information support, environmental problems

\section{Introduction}

Economic growth and development are one of the main concerns of economists and policymakers in every country. In order to target and plan for improvement in economic growth, accurate identification of the factors affecting it is inevitable. Labour and physical capital have been factors that have been considered in many studies (Busheneva, \& Stetsyunich, 2018). However, in recent decades, some studies have introduced these concepts by introducing the concept of environment. The environment is a very large and complex set of various factors that affect and are affected by human performance and activities (Maron et al., 2018; Burns et al., 2020; Gangi et al., 2020). Therefore, this concept implies that the subject of the environment encompasses a wide range of different dimensions. On the other hand, each country considers different goals and programs in order to achieve growth and development. But to achieve these goals, developing countries are facing the problem of environmental degradation. Because most economic activities depend on the use of natural resources and less activity can be found that ultimately does not lead to the creation of environmental waste. Thus, economic development, taking into account environmental considerations, has long been the focus of economists. If in the framework of development programs, the economic activities of the government and the environment are considered together; These two factors are complementary to each other and cause ecological balance. Therefore, in order to move in the direction of development, not only the environment and economic development are not two opposite poles; Rather, both are a factor in the balanced promotion of societies (Alons, 2017; Li et al., 2017; Liao, 2018; Xu et al., 2018). 
The policy is a set of measures by which the ruling elite, represented by the government, legislative bodies, ensures the management of social development in order to meet the needs and interests of citizens, to maintain order and stability in accordance with the country's constitution. This term is also used to describe laws, mandates or regulations established within the political process of the state (Grachev, 2004; Alekseev et al., 2016; Meyer, 2002; McCombs, 2004). The key attributes of policy are political actions that arise as a response to a problem requiring an urgent solution (Bennett \& Entman, 2001). The environmental policy includes actions made by the government at the federal, regional and local levels to safeguard the environment and protect natural resources (Duan et al., 2012). The actions which done by the state to protect the environment are associated with solving many other problems, for example, the problem of ensuring economic growth, the search for new energy sources, the observance of the rights of enterprises and individuals, which significantly affect the effectiveness of the environmental policy. At the same time, the coordination of actions of the federal and regional authorities is extremely important in the implementation of the state environmental policy, which requires a search for consensus, mutual concessions, reaching a compromise within the framework of existing legislation (Adriaanse, 1993; Jaffe et al., 2002; Miller, 2000; Smith, 2000; Teets, 2018). The roots of environmental policies dating back to the 1960s show that these issues are reaching their mid-maturity. Throughout human history, groups, societies and civilizations have been in contact with their environment. But it is only modern nation-states that have considered environmental issues as a political issue since the early 1960s. Historically, not much time has passed since the 1960s. But in this short time, a high motivation has been formed in different societies to consider environmental policies as vital and to try to make them operational (Busheneva, \& Stetsyunich, 2018; Shahab et al., 2018; Metze, 2020).

The government is one of the most important economic sectors of any country, which in the form of legislation and economic security, provides a suitable environment for the optimal allocation of resources, as well as economic growth and development. In fact, by creating facilities and infrastructure, it plays a role in increasing economic efficiency. Therefore, by implementing economic policies, it affects the activities of other economic sectors. In the economic literature, there are different views and theories about government involvement in economic activities, which are generally divided into two main groups:

- In the first view, it is assumed that in the context of government activities, economic growth and development are of paramount importance. Thus, economic growth is achieved by delegating economic decisions to individuals or private institutions. On the other hand, the productivity of government economic activities is much lower than the private sector and the role of government, especially in the labour and capital markets, is an obstacle to corporate investment activities. Therefore, government interference in economic activities leads to undesirable allocation of resources and inefficiency in the system.

- The second view considers the role of the government necessary in achieving the goals of economic development because the vast volume of government activities is more powerful to drive the engine of economic development. Therefore, the government's intervention in increasing effective investments to promote the country's economic growth and development is justified.

Information support of state policy is an important factor in its effectiveness. As a communication channel between the governing bodies and the population, coverage of the state's activities performs not only an information function but also a communication and organizational function, seeking to form the significance of the measures taken in the public consciousness, their approval and support from citizens. In this regard, a particular place is engaged by the information support of the state's efforts in the environmental conservation and protection field. The designated problems are a matter of concern not only for national states but for all over the world. The ecological crisis, which disrupted the human environment, changed the planet's natural balance, extremely exacerbated contradictions in the "society-nature" system and raised the question of our civilization future existence with all its urgency (Shkiperova, \& Druzhinin, 2018). The emerging environmental problems have affected almost all fields of public life. First of all, the negative impact of the unfolding environmental crisis affected the economic growth, causing difficulties in solving national economic problems, which could neither negatively affect the social and demographic situation in the world, causing not only an aggravation of the existing problems but also the emergence of new ones related to the state of human health and living conditions. Negative changes in the environment caused by unbalanced, predatory environmental management forced the international community to reconsider the existing relationship between nature and human, not only to intensify the participation of national states in ensuring environmental safety but also combining their efforts to compensate for the damage caused to the environment (Mol, 2009; Gifford \& Comeau, 2011; Korppoo et al., 2015).

The main tool that regulates human relations with the environment in accordance with the laws protecting nature and 
ensuring environmental safety, using all feasible channels for the foundation of a civilized individual's approach to the environment, is the state environmental policy (Matveeva, 2010). Its effectiveness, as a factor in optimizing relations between society and environment, the rational resource use, is largely determined by timely, complete and active coverage of problems in the environmental development, communicating to the population the importance of each individual's personal responsibility for preserving the habitat, available natural resources, and deliberately limiting material needs. In accordance with the Federal Law of the Russian Federation No. 7-FZ dated January 10, 2002 "On Environmental Protection", Article No. 11 "Rights and Obligations of Citizens in the Field of Environmental Protection", and with the current Constitution of the Russian Federation, "every citizen has the right to a favourable environment, its protection from negative impacts caused by economic and other activities, natural and man-made emergencies, reliable information on the environmental status, as well as compensation for environmental damage" (Federal Law No. 7-FZ dated January 10, 2002). This law is basic in the activities of the Russian Federation to preserve the environment and determines the main directions of the modern state environmental policy (Feldman, 2012; Busheneva, \& Stetsyunich, 2018; Balabanova et al., 2019).

\section{Methods}

The environment is a very pervasive field due to its actions and reactions with other economic, social and cultural sectors. Economically, it is a provider of production inputs and a factor influencing economic growth; Socially, healthy living space is a requirement of a healthy society that includes natural and climatic features and the national customs and traditions and patriotic and historical identity of each country evolve and develop in accordance with it. It is obvious that the development and continuation of economic growth at the cost of nature destruction will not be sustainable in the long run. Therefore, paying attention to environmental considerations, recognizing the existing challenges facing countries in the process. Figure 1 shows the Ranking of environmental policies according to their contribution to sustainable development (Pojani et al., 2013).

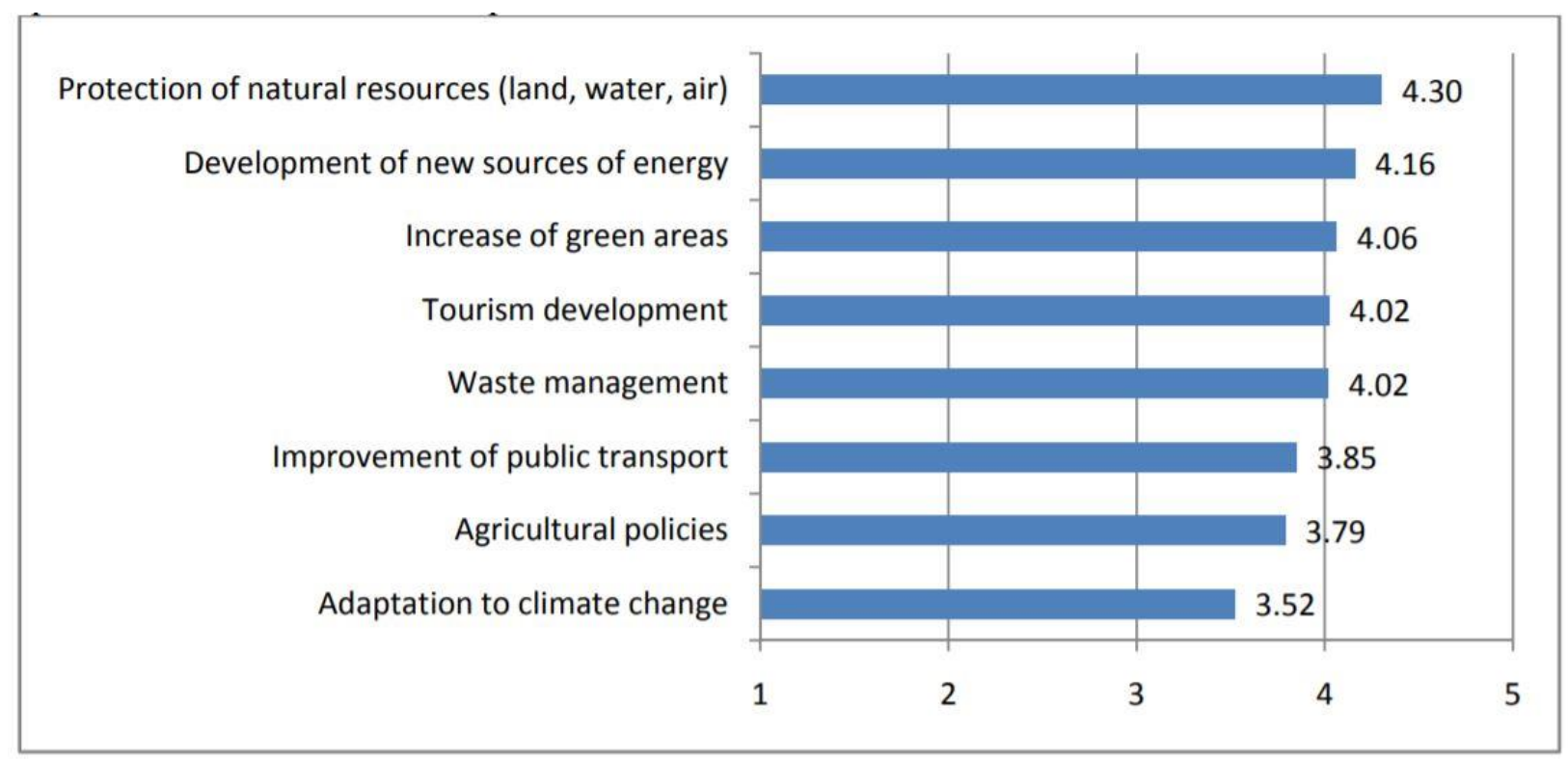

Figure 1. Ranking of environmental policies according to their contribution to sustainable development (Pojani et al.,

National development policies are needed as the most important priority in economic, social and political decisions. Environmental policies have components and rules, the most important of which are as follows:

A) the right of access to environmental information;

B) the right to participate in environmental decision-making;

C) The right to education on environmental issues; 
D) The right of access to administrative and judicial authorities, including punishment and compensation for environmental damages.

These rules are contained in most international agreements, including the Rio Declaration, the Sofia Strategic Principles of 1995, the International Convention on the Right to Information and Public Participation in the Environment of Denmark, the International Convention on the Right to Information, and Public Participation in the Environment (1998), European Convention on Human Rights (Article 10), Climate Change Convention (Article 6), Geneva Protocol on Mediterranean Protected Areas, Kingston Protocol on Marine Wildlife Conservation Caribbean (Article 1), Nairobi Protocol on Protected Areas and Wildlife in East Africa (Article 15), United Nations Structural Convention on Climate Change (Article 1, Paragraph 1), Convention on Biological Diversity (Articles 13 and 17) etc. have been elaborated.

The inductive analysis of the content of the official websites of the MENR of the Republic of Tatarstan and the Ministry of Natural Resources and Ecology of the Russian Federation carried out within the study made it possible to identify the specific nature of covering the activities of regional authorities in the field of environmental safety. The materials content analysis of the regional media made it possible to reveal the peculiarities in the information coverage of the state environmental protection measures of the MENR of the Republic of Tatarstan and the Ministry of Natural Resources and Ecology of the Russian Federation.

\section{Results and Discussion}

Studying the activities of the MENRof the Republic of Tatarstan related to the implementation of its main functions management in the use of natural resources, environmental protection, radiation safety, control of the radiation situation in the Republic of Tatarstan, regulation of subsoil use relations, management of the study, use and reproduction of the mineral resource base, regulation of relations in the field of using subsoil plots of local significance - was carried out based on the materials investigations posted on the official websites of the Ministry of Natural Resources and Ecology of the Russian Federation and the MENRof the Republic of Tatarstan. The study time frames cover the period from January 2015 to December 2019.

The results of the content analysis of the official websites of the ministries on the highlighted topics of material coverage are given in Table 1. When comparing the total volume of publications on the website of the MENRof the Republic of Tatarstan, there were 244 items more posted than on the website of the Ministry of Natural Resources and Ecology of the Russian Federation (3866 vs. 3622). Content analysis of publications, carried out according to the criterion of their content, showed that the information posted on the website of the Ministry of Natural Resources and Environment (MNRE) of the Russian Federation is more related to coverage of legal issues, legislative acts, official documents in the field of environmental policy. Thus, there are more than four times more publications related to the coverage of laws, plans, official press conferences held on this occasion on the website of the federal ministry than on the website of the regional department for the same period (2,452 vs. 577). The website content of the MENRof the Republic of Tatarstan is distinguished by great attention to information coverage of the state measures aimed at solving environmental problems, events, forums, exhibitions held in this regard, as well as events related to the environmental education and public awareness, environmental violations in the republic. Thus, there are seven times more identified environmental violations on the website of the MENRof the Republic of Tatarstan.

Table 1. The number of publications on the websites of the Ministry of Natural Resources and Ecology of the Russian Federation and the MENRof the Republic of Tatarstan for 2015-2019

\begin{tabular}{cccc}
\hline Feature category & $\begin{array}{c}\text { Contests, conferences, environmental } \\
\text { forums, environmental exhibitions } \\
\text { and environmental lectures }\end{array}$ & $\begin{array}{c}\text { Laws, plans, official } \\
\text { press conferences }\end{array}$ & $\begin{array}{c}\text { Identified } \\
\text { environmental } \\
\text { violations }\end{array}$ \\
\hline $\begin{array}{c}\text { MNRE of the Russian } \\
\text { Federation }\end{array}$ & 1126 & 2452 & 44 \\
\hline $\begin{array}{c}\text { MENRof the Republic } \\
\text { of Tatarstan }\end{array}$ & 2963 & 577 & 326 \\
\hline
\end{tabular}

Comparative analysis of the press activities office of the Ministry of Natural Resources and Ecology of the Russian Federation and the MENRof the Republic of Tatarstan shows that the press office of the federal ministry posted almost 3.5 times fewer publications than the regional department for the period under review (76 vs. 259). 
The bulk of materials of the MNRE of the Russian Federation were published in electronic media such as Izvestia, Vedomosti, Lenta.ru, Rbk.ru, Rossiyskaya Gazeta, Kommertant, TASS, Interfax, Moskovsky Komsomolets, Komsomolskaya Pravda, Argumenty i Fakty, etc.

Most of the publications were placed in the following editions in the regional media by the press office of the MENRof the Republic of Tatarstan:

- Information Agency "Tatar-inform" (Kazan residents discovered a discharge of wastewater with a specific smell into the lake of Zalesny village);

- Electronic periodical www.prokazan.ru(Ecologists: wastewater was poured into the lake in Zalesny village);

- Internet Newspaper "Vechernyaya Kazan" (A wastewater discharge into the lake was found in Zalesny village);

- Network Publication "Komsomolskaya Pravda": (Environmentalists are engaged in lake pollution in Kazan);

- Online Edition "Sobytiya": (Zalesny village residents complained about the wastewater discharge);

- Internet Newspaper "Realnoe Vremya": (Environmentalists have identified wastewater discharge into one of the lakes in Kazan);

- Internet Portal "TatCenter.ru": (Ministry of Ecology of the Republic of Tatarstan detected wastewater discharge into the lake located in Zalesny village);

- Internet Edition "Kazansky Reporter": (Kazan residents complained about lake pollution in Zalesny village (Figure 2).

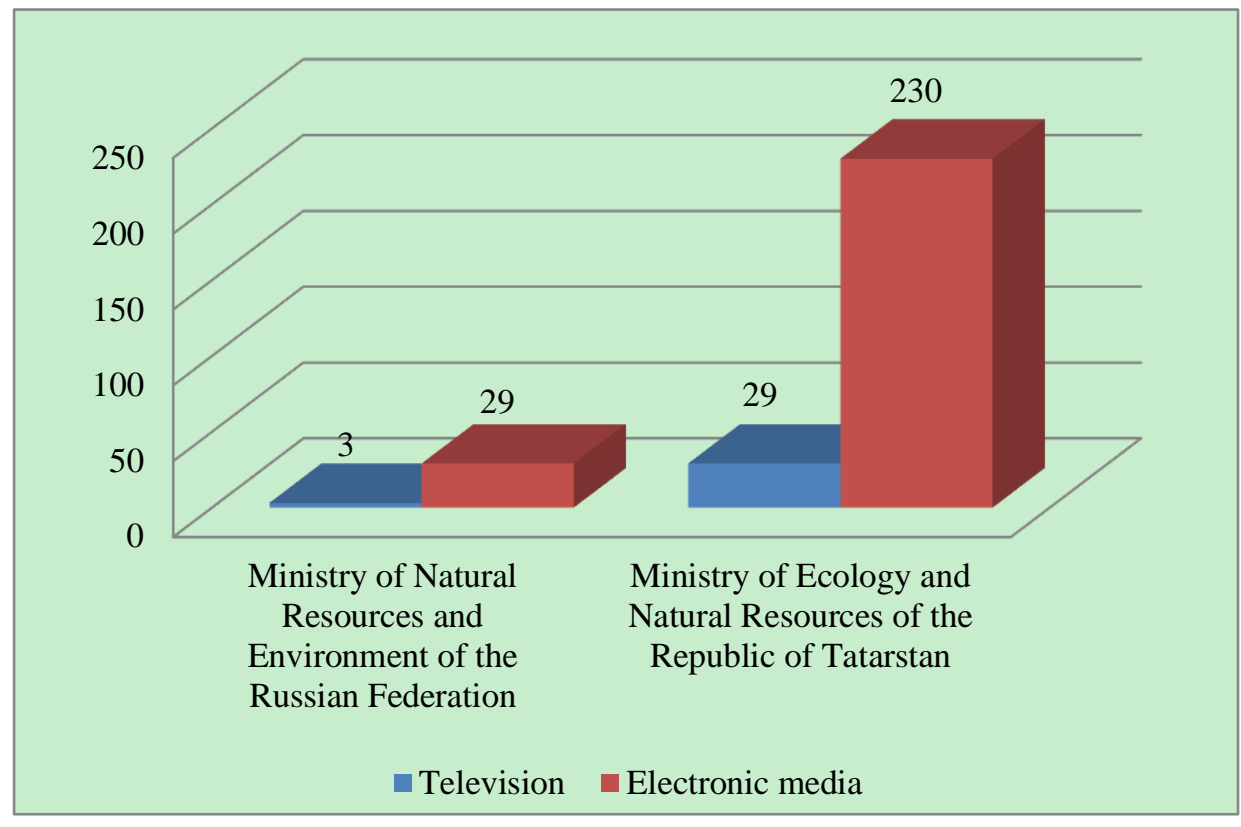

Figure 2. Publications in the media of the press offices of the ministries for 2015-2019

An important aspect of the research was the possibility study of citizens' access to a communication channel with the state authority in charge of environmental protection. Table 2 shows the results of a comparative analysis of resources that provide access to the population for contacting a government agency, and the possibility of feedback from the "Ministry of Natural Resources and Ecology of the Russian Federation" and the "MENRof the Republic of Tatarstan" to the population.

The results obtained make it possible to assert that the communication relationship of the regional government body with citizens is more intense than that of the federal agency. Thus, there is a Republican Public Ecological Reception under the MENRof the Republic of Tatarstan, which interacts through such channels as telephone, e-mail, information system "People's Control", mobile application "School Eco-Patrol", a contact number via WhatsApp or Telegram, makes a personal appointment through the ministry's reception. 
Table 2. Communication resources of the "Ministry of Natural Resources and Ecology of the Russian Federation" and the "MENRof the Republic of Tatarstan" with citizens for 2015-2019

\begin{tabular}{ccc}
\hline $\begin{array}{c}\text { Department's communication } \\
\text { resources with citizens }\end{array}$ & MNRE of the Russian Federation & $\begin{array}{c}\text { Ministry of Natural Resources and } \\
\text { Ecology of the Republic of } \\
\text { Tatarstan }\end{array}$ \\
\hline $\begin{array}{c}\text { Official website with access to the } \\
\text { Internet reception }\end{array}$ & Available & Available \\
\hline Unified hotline & Available & Available \\
\hline $\begin{array}{c}\text { Specialized application } \\
\text { (available in test mode) }\end{array}$ & $\begin{array}{c}\text { School Eco-Patrol } \\
\text { People's Control ("Ecology" } \\
\text { category) }\end{array}$ \\
\hline $\begin{array}{c}\text { "VKontakte" social network, } \\
\text { number of subscribers }\end{array}$ & 679 & 1813 \\
\hline "Telegram" messenger & Not available & Available \\
\hline $\begin{array}{c}\text { "WhatsApp" instant messaging } \\
\text { system }\end{array}$ & Not available & Available \\
\hline $\begin{array}{c}\text { "Instagram" application, } \\
\text { publications }\end{array}$ & Not available & 1765 \\
\hline $\begin{array}{c}\text { "Instagram" application, } \\
\text { subscribers }\end{array}$ & Not available & 8694 \\
\hline
\end{tabular}

To increase the activity of the republic's population, to attract citizens to solving environmental problems, the ministry provides incentives in the form of a monetary equivalent. A bonus of 1,500 roubles is paid for a photo or video recording of relevant information containing confirmation of environmental legislation violations, which is reflected on the official website of the department. The MENRof, the Republic of Tatarstan, receives on average about 13,000 messages of this kind during the year. According to statistics provided by the Ministry of Ecology and Nature Management of the Republic of Tatarstan for 2019, (https://ex.kpfu.ru/owa/redir.aspx?C=KrLip6oqALsPf3nzWJlzwswGef1y6N2K_9NsA9GeXfiTPbPOcC3YCA..\&U $\mathrm{RL}=\mathrm{https} \% 3 \mathrm{a} \% 2 \mathrm{f} \% 2 \mathrm{feco.tatarstan} . \mathrm{ru} \% 2 \mathrm{f}$ ), a total of $13 \mathrm{~m} 944$ appeals were received from the republic's population.

According to the results obtained, the most popular communication channel between the citizens and the ministry was the State Information System of the Republic of Tatarstan "School Eco-Patrol" (8,652 calls per year). The second position is occupied by such a form of appeal to a state body as an appointment through the ministry's reception and personal reception of the republic citizens (2,153 appeals per year). The next group of calls is occupied by messages recorded through additional communication channels - WhatsApp, Telegram, Eco. signal and the ministry's hotline (1,706 calls per year). 1,433 notifications were registered through the State Information System of the Republic of Tatarstan "People's Control".

The data obtained from the analysis of citizens' appeals to the Republican Public Ecological Reception allows making a certain rating of environmental problems in the region: the most significant topic was the problem of waste recycling with a share of $86 \%$, air purity $-7.81 \%$, water purity $-3.51 \%$, sanitary conditions in the region $-1.82 \%$ and illegal mining of common minerals - $0.9 \%$.

According to the results obtained, the MENRof the Republic of Tatarstan pays great attention to attracting the younger generation to ensure environmental safety. Thus, the department actively uses the Mobile Application "School Eco-Patrol" for information communication with the population. In accordance with the instruction of the President of the Republic of Tatarstan to involve schoolchildren in practical work to establish sanitary order, an annual competition is held among students of different educational organizations using a specially developed Mobile Application "School Eco-Patrol", which ensures the delivery of photo or video messages with recorded violations of the environmental legislation of the Republic of Tatarstan.

For effective interaction of the republic population with the state authorities, it was created the State Information System of the Republic of Tatarstan "People's Control" ("Ecology" category), which provides prompt notification via 
the Internet or through a mobile application in the categories "Landfills", "Water", "Air", "Illegal Quarries", "Sanitary Condition", "Corruption in Ecology" and "Illegal Extraction of Common Mineral Resources at a Water Body".

Since 2019, the MENRof the Republic of Tatarstan has been publishing the monthly magazine "S Chistogo Lista". It reflects the main environmental projects of the republic, interviews with experts, events and winners of eco-competitions held by the Ministry. All issues are available in electronic format on the ministry's official website. The television program "Chisty Tatarstan" (broadcast once a week) discusses the problems of ecology and environmental protection with answers on the air: how to preserve natural resources, clean air and water bodies, how to deal with illegal garbage dumps.

According to the data obtained, an important interaction channel between the MENRof the Republic of Tatarstan and the media is the monitoring system "Incident Management", which allows tracking news on five social networks (Facebook, Instagram, Twitter, VKontakte, Odnoklassniki). Statistics are kept on all processed and unprocessed "incidents", which can be observed in real-time by the employees of municipal and regional administrations, as well as by the presidential administration using the program, with the obligatory processing of each "incident" within 24 hours from its registration in the system.

The MENRof, the Republic of Tatarstan, annually organizes a republican competition "Ecoleader" with the participation of individual entrepreneurs, local authorities, educational organizations, public associations, citizens and media in the field of industry to attract the population to participate in solving the environmental problems.

The most significant event of the MENRof the Russian Federation in ensuring environmental safety is the national project "Ecology". The project "Ecology" includes 12 national projects, of which eight are being implemented on the territory of the Republic of Tatarstan. The effectiveness of information support for ongoing environmental projects was measured using content analysis of high-rated regional media: "Realnoe Vremya", "Business Online", "Vechernaya Kazan" for 2015-2019.

The obtained quantitative indicators of publications and mentions on the subject in the regional media under the project "Ecology" are given in Table 3. The total number of publications on the national project "Ecology" in the regional media was 614, of which more than two thirds (69.4\%) accounted for "Business Online", one-quarter of materials (24.3) - "Realnoe Vremya" and 6.3\% - "Vechernyaya Kazan". At the same time, there are very few publications related to solving specific problems of the environment. In general, they are single. Only three main topics can be distinguished by publications in "Business Online":

- Volga improvement - 71 publications;

- Preservation of forests - 65 materials;

- Preservation of unique water bodies - 65.

Table 3. Quantitative indicators of references in the regional media to the problems of the project "Ecology

\begin{tabular}{cccc}
\hline Project & Realnoe Vremya & Business Online & Vechernaya Kazan \\
\hline National Project "Ecology" & 149 & 426 & 39 \\
\hline Clean country & 2 & 9 & 0 \\
\hline MSW & 3 & 3 & 19 \\
\hline Clean water & 0 & 71 & 4 \\
\hline Volga improvement & 5 & 49 & 0 \\
\hline $\begin{array}{c}\text { Preservation of biological diversity } \\
\text { and development of ecological } \\
\text { tourism }\end{array}$ & 2 & 3 & 0 \\
\hline $\begin{array}{c}\text { Preservation of forests } \\
\text { Implementation of the best available } \\
\text { technologies }\end{array}$ & 0 & 65 & 4 \\
\hline
\end{tabular}


The obtained results of the information support comparative analysis of state environmental policy at the federal and regional levels of government, the content of the official websites of the MENRof the Republic of Tatarstan and the Ministry of Natural Resources and Ecology of the Russian Federation, the work of press offices allow asserting that there is insufficient media coverage of the problems of ensuring environmental safety. Thus, according to the most significant national project "Ecology" in Russia today, there are very few publications related to solving specific environmental problems, they are not of a systemic, analytical nature that attracts the attention of the public and the authorities to the need to solve them. According to the data obtained from the content analysis of regional media, such significant projects as "Preservation of Biological Diversity and Development of Ecological Tourism" and "Clean country" have the lowest rates.

The study of the possibility of citizens' access to a communication channel with the state authorities in charge of environmental protection at the federal and regional levels allows making a conclusion that the communication between regional government and citizens is more intense than that of the federal agency.

\section{Conclusions}

Increasing the effectiveness of information support of the state environmental policy requires increased public attention of the authorities to the problems that have arisen in the human environment through, first of all, more intensive use of all information resources of the MENRof the Russian Federation, the MENRof the Republic of Tatarstan: official websites, press offices, and media.

The forms of environmental issues shall also be fundamentally new, focusing the population's attention on information about eliminated environmental offences, environmental education and enlightenment of the younger generation. It is necessary to strengthen coverage of incidents and disasters in the field of ecology, materials with predicting threats to the existence of the entire civilization.

\section{Acknowledgements}

The work is performed according to the Russian Government Program of Competitive Growth of Kazan Federal University.

\section{References}

Adriaanse, A. (1993). Environmental policy performance indicators (p. 175). The Hague: SDU.

Alekseev, V. M., Alekseeva, M. S., \& Khalyapin, A. A. (2016). Principles of Environmental Policy in Modern Conditions. Scientific Problems, 33(75), 12-14.

Alons, G. (2017). Environmental policy integration in the EU's common agricultural policy: greening or greenwashing?. Journal of European Public Policy, 24(11), 1604-1622.

Balabanova, A., Keschyan, N., Borisova, T., \& Hachemizova, E. (2019). The environmental policy implementation of the city of Sochi (Russia). In E3S Web of Conferences (Vol. 91, p. 08019). EDP Sciences.

Bennett, W. L., \& Entman, R. M. (Eds.). (2000). Mediated politics: Communication in the future of democracy. Cambridge University Press.

Burns, C., Eckersley, P., \& Tobin, P. (2020). EU environmental policy in times of crisis. Journal of European Public Policy, 27(1), 1-19.

Busheneva, Y. I., \& Stetsyunich, Y. N. (2018). Financing of the activities of the regional environmental policy in the Russian Federation on the example of the Leningrad region. International Multidisciplinary Scientific GeoConference: SGEM, 18(5.3), 383-388.

Duan, H., bin Chik, A. R., \& Liu, C. (2012). Institutional environment and capital structure: Evidence from private listed enterprises in China. International Journal of Financial Research, 3(1), 15-21.

Federal Law No. 7-FZ dated January 10, 2002. (as amended on December 27, 2019). On Environmental Protection.

Feldman, D. L., \& Blokov, I. (2012). The politics of environmental policy in Russia. Edward Elgar Publishing.

Gangi, F., Daniele, L. M., \& Varrone, N. (2020). How do corporate environmental policy and corporate reputation affect risk-adjusted financial performance?. Business Strategy and the Environment.

Gifford, R., \& Comeau, L. (2011). Message framing influences perceived climate change competence, engagement, and behavioral intentions. Global Environmental Change, 21, 1301-1307.

Grachev, M. N. (2004). Political communication: theoretical concepts, models, vectors of development. M.: 
Prometheus, 328.

Jaffe, A. B., Newell, R. G., \& Stavins, R. N. (2002). Environmental policy and technological change. Environmental and Resource Economics, 22(1-2), 41-70.

Korppoo, A., Tynkkynen, N., \& Hønneland, G. (2015). Russia and the politics of international environmental regimes: Environmental encounters or foreign policy?. Edward Elgar Publishing.

Li, J., Zhao, F., Chen, S., Jiang, W., Liu, T., \& Shi, S. (2017). Gender diversity on boards and firms' environmental policy. Business Strategy and the Environment, 26(3), 306-315.

Liao, Z. (2018). Environmental policy instruments, environmental innovation and the reputation of enterprises. Journal of Cleaner Production, 171, 1111-1117.

Maron, M., Brownlie, S., Bull, J. W., Evans, M. C., von Hase, A., Quétier, F., ... Gordon, A. (2018). The many meanings of no net loss in environmental policy. Nature Sustainability, 1(1), 19-27.

Matveeva, E. V. (2010). Environmental Policy of Modern Russia. News of Altai State University, 4(1), 303-308

McCombs, M., \& Valenzuela, S. (2020). Setting the agenda: Mass media and public opinion. John Wiley \& Sons.

Metze, T. (2020). Visualization in environmental policy and planning: a systematic review and research agenda. Journal of Environmental Policy \& Planning, 22(5), 745-760.

Meyer, T. (2002). Media democracy: How the media colonize politics. Polity, 184.

Miller, T. G. (2000). Living in Environment, p. 459 (Figure 17-13), p. 547.

Mol, A. P. (2009). Environmental deinstitutionalization in Russia. Journal of Environmental Policy \& Planning, $11(3), 223-241$.

Pojani, E., Grabova, P., \& Kodhelaj, M. (2013). Climate change impacts: Public policies and perception in Albania. Albanian Journal of Agricultural Sciences, 12(4).

Shahab, Y., Ntim, C. G., Chengang, Y., Ullah, F., \& Fosu, S. (2018). Environmental policy, environmental performance, and financial distress in China: Do top management team characteristics matter?. Business Strategy and the Environment, 27(8), 1635-1652.

Shkiperova, G. T., \& Druzhinin, P. V. (2018). Evaluating the Efficiency of the Environmental Security Policy in the Russian Regions. National Interests: Priorities and Security, 14(12), 2356-2372.

Smith, J. (2000). The Daily Globe. Environmental Change, the public and the media. Earthscan Publications Ltd, London; Anton, C. History, orientations, and future directions of media ecology. In Pasadeos, Y., \& Dimitrakopoulou, D. (Eds.), Mass Media Research: International Approaches (2006, p. 299). Athens Institute for Education and Research: Athens, Greece.

Teets, J. (2018). The power of policy networks in authoritarian regimes: Changing environmental policy in China. Governance, 31(1), 125-141.

$\mathrm{Xu}$, M., David, J. M., \& Kim, S. H. (2018). The fourth industrial revolution: Opportunities and challenges. International Journal of Financial Research, 9(2), 90-95.

\section{Copyrights}

Copyright for this article is retained by the author(s), with first publication rights granted to the journal.

This is an open-access article distributed under the terms and conditions of the Creative Commons Attribution license (http://creativecommons.org/licenses/by/4.0/). 